\title{
PERAN DUKUNGAN KELUARGA TERHADAP PEMENUHAN KEBUTUHAN TIDUR PASIEN HEMODIALISIS
}

\section{The Role of Family Support for Fulfilling Sleep Needs of Hemodialysis Patients}

\section{Argo Winoto*1, Kusnanto2, Muhammad Sajidin3}

1. Mahasiswa Fakultas Keperawatan Universitas Airlangga

2. Fakultas Keperawatan Universitas Airlangga

3. Stikes PPNI Bina Sehat, Mojokerto

\section{Riwayat artikel}

Diajukan: 5 Agustus 2019

Diterima: 28 Maret 2020

\section{Penulis Korespondensi:}

- Argo Winoto

- Fakultas Keperawatan,

Universitas Airlangga

argo.winoto85@gmail.co

$\underline{\mathrm{m}}$

\section{Kata Kunci:}

Dukungan keluarga, Tidur, Hemodialisa

\begin{abstract}
Abstrak
Pendahuluan: Dukungan dari keluarga terhadap pasien hemodialisis sangat diperlukan. Namun sampai dengan saat ini belum ada penelitian yang secara khusus membahas bentuk dukungan yang diberikan oleh keluarga pada pasien hemodialisis sehingga tidak mengalami gangguan kualitas tidur. Tujuan dari penelitian ini untuk mengkaji secara mendalam upaya dukungan yang diberikan oleh keluarga kepada salah anggota keluarga yang sedang menjalani hemodialisis. Metode: Penelitian ini adalah penelitian qualitative dengan studi fenomenologi. Jumlah sample adalah 14 partisipan yang diambil dengan cara purposive sampling. Kriteria partisipan adalah pasien hemodialisis yang dapat memenuhi kebutuhan tidurnya yang ditandai dengan skala ukur Pitsburg Sleep Quality Indeks (PSQI $\leq 5$ ). Partisipan direkam saat wawancara mendalam terkait pengalaman hidup mereka sehari-hari dengan menggunakan pedoman semi-struktur. Proses analisa data pada penelitian ini menggunakan metode Colaizzi. Hasil: Terdapat 3 tema utama yang diperoleh dari hasil analisis data wawancara antara lain dukungan keluarga, dukungan lingkungan dan dukungan tenaga kesehatan. Berdasarkan hasil ketiga tema utama tersebut maka dukungan keluarga yang menjadi faktor terbanyak yang membuat kualitas tidur pasien menjadi lebih baik. Tema utama dukungan keluarga dapat diuraikan menjadi tiga sub tema, yaitu kebutuhan akan pendamping, membantu memenuhi kebutuhan, dan perhatian. Diskusi: Dukungan keluarga akan memunculkan rasa aman, nyaman dan menumbuhkan harapan bagi pasien hemodialisis sehingga akan menimbulkan ketenangan yang dapat memudahkan pasien untuk memenuhi kebutuhan tidurnya.
\end{abstract}

\section{Abstract}

Introduction Family support for hemodialysis patients is needed. But until now there has been no research that specifically discusses the form of support provided by families in hemodialysis patients so that they do not experience sleep quality disorders. The purpose of this study is to examine in depth the support efforts provided by the family to one family member who is undergoing hemodialysis. Method: This research is a qualitative study with a phenomenological study. The number of samples was 14 participants taken by purposive sampling. Criteria for participants are hemodialysis patients who can meet their sleep needs which are marked by the Pitsburg Sleep Quality Index $(P S Q I \leq 5)$ scale. Participants were recorded during in-depth interviews related to their daily life experiences using semi-structural guidelines. The process of analyzing data in this study uses the Colaizzi method. Results: There are 3 main themes obtained from the analysis of interview data including family support, environmental support and support of health workers. Based on the results of the three main themes, family support is the most important factor that makes the quality of sleep for patients better. The main themes of family support can be broken down into three sub-themes, namely the need for companions, helping meet needs, and attention. Discussion: Family support will bring a sense of security, comfort and hope for hemodialysis patients so that it can create a calm that can make it easier for patients to fulfill their sleep needs. 


\section{PENDAHULUAN}

Salah satu terapi pengganti fungsi ginjal yang cara kerjanya memproses pengeluaran cairan dan produk limbah dari dalam tubuh adalah hemodialisis (Smeltzer \& Bare, 2002). Hemodialisis adalah terapi yang paling umum dijalani penderita gagal ginjal kronis tahap akhir di dunia. Pada akhir tahun 2016, jumlah pasien penyakit ginjal kronik (PGK) yang menjalani dialisis diperkirakan mencapai 2.989 .000 dan $89 \%$ di antaranya menggunakan terapi hemodialisis (Shahgholian \& Yousefi, 2018). Hasil dari Riset Kesehatan Dasar (Riskesdas) tahun 2018 menunjukkan bahwa jumlah penderita PGK di Indonesia sebesar 3.8 permil atau 3,8 per 1000 penduduk. Berdasarkan Indonesian Renal Registry (IRR) tahun 2016, sebanyak 98\% penderita penyakit ginjal kronik menjalani terapi hemodialisis sebagai terapi pengganti.

Terapi hemodialisis yang dijalani pasien PGK dapat memperpanjang usia, namun pada waktu yang bersamaan terapi tersebut dapat memberikan dampak pada perubahan fungsi biologis tubuh, salah satunya adalah perubahan kualitas tidur (Zubair \& Butt, 2017; Shahgholian \& Yousefi, 2018). Menurut Eslami, (2014) bahwa sejumlah $80 \%$ pasien yang menjalani hemodialisis mengalami gangguan kualitas tidur yang ditandai dengan kesulitan untuk segera tertidur, sulit untuk mempertahankan tidur atau sering terbangun saat tidur dan tidur yang berlebihan pada siang hari. Kualitas tidur yang buruk tersebut dapat menimbulkan kelelahan, mengantuk, gangguan aktivitas sehari-hari (terutama pada siang hari), gangguan kualitas hidup yang berhubungan dengan kesehatan (Quality of Life) dan peningkatan morbiditas serta mortalitas (Momennasab, Ranjbar, \& Najafi, 2018).

Penyebab terjadinya gangguan tidur pada pasien yang menjalani hemodialisis adalah multifaktorial sehingga upaya untuk mengatasi penyebabnya diperlukan dukungan yang holistik (Eslami et al., 2014). Salah satu dukungan terdekat yang dapat diperoleh adalah dari anggota keuarga. Keluarga berfungsi sebagai sistem pendukung bagi anggotanya dengan pandangan bahwa orang yang bersifat selalu siap mendukung dan memberikan pertolongan jika diperlukan (Setiadi, 2008 dalam Febriastuti, 2015). Dukungan keluarga merupakan faktor yang penting bagi seseorang ketika menghadapi masalah kesehatan yang dapat berperan dalam fungsi sebagai keperawatan kesehatan anggota keluarganya untuk mencapai kesehatan yang optimum (Sukriswati, 2016). Dukungan keluarga dibutuhkan pasien GGK yang menjalani hemodialisis untuk mendapatkan perhatian dari keluarganya dan juga dukungan harga diri. Bentuk dukungan ini berupa penghargaan positif terhadap individu, pemberian semangat, persetujuan terhadap pendapat individu, perbandingan yang positif dengan individu lain (Taylor, 1999). Secara umum terdapat 5 (lima) dimensi dukungan keluarga yang diberikan oleh anggota keluarga (Friedman, Bowden, \& Jones, 2010) yaitu dukungan emosional, dukungan penghargaan, dukungan informasi, dukungan instrumental, dan dukungan jaringan sosial yang kesemuanya menjadi satu bentuk dukungan keluarga. Sampai dengan saat ini belum terdapat studi literatur yang secara spesifik membahas tentang bentuk dukungan keluarga yang dapat berpengaruh terhadap kualitas tidur pasien PGK yang menjalani hemodialisis. Dengan penelitian yang menggunakan metode kualitatif ini, peneliti berupaya menggali informasi tentang bentuk dukungan keluarga yang diberikan pada anggota keluarga yang menjalani hemodialisis sehingga dapat memenuhi kebutuhan tidurnya.

\section{METODE}

Studi penelitian ini menggunakan rancangan penelitian kualitatif dengan pendekatan fenomenologi. Teknik pengambilan sampel yaitu purposive sampling dengan kriteria partisipan dalam penelitian ini adalah pasien PGK yang sudah menjalani hemodialisis di Rumah Sakit Haji Surabaya minimal 6 bulan dan mempunyai kualitas tidur baik. Penentuan kualitas tidur baik menggunakan alat ukur PSQI (Pitsburg Sleep Quality Indeks) apabila nilai PSQI kurang dari sama dengan 5 (PSQI $\leq 5)$. Metode yang digunakan untuk pengumpulan data menggunakan teknik wawancara secara mendalam (in depth interview) terhadap sejumlah 14 orang partisipan terkait bentuk dukungan keluarga sehari-hari kepada anggota keluarga yang menjalani hemodialisis sehingga bisa memenuhi kebutuhan tidurnya. Peralatan yang digunakan selama proses wawancara menggunakan alat perekam, field note, dan pedoman pertanyaan semi-struktur. Wawancara dalam penelitian ini dilakukan sesuai dengan kesepakatan partisipan yaitu di Ruang Hemodialisis RS Haji Surabaya selama partisipan menjalani hemodialisis atau di rumah partisipan. Waktu yang dibutuhkan untuk wawancara tiap partisipan lebih kurang 1 jam. Proses pengumpulkan data dengan metode wawancara kurang lebih satu bulan yang dimulai sejak tanggal 29 April sampai dengan 31 Mei 2019.

Data yang sudah terkumpul dianalisa menggunakan langkah-langkah metode Colaizzi yaitu, (1) peneliti membaca dan menggabungkan seluruh deskripsi fenomena dari hasil wawancara, (2) membaca kembali transkrip dan mengutip pernyataan yang bermakna dari hasil wawancara dengan partisipan, (3) menguraikan arti yang ada di dalam pernyataan bermakna, (4) mengorganisir kumpulan kategori ke dalam kelompok tema, (5) menuliskan deskripsi yang lengkap, (6) menemui partisipan untuk melakukan validasi deskripsi hasil 
analisis, (7) menggabungkan data hasil validasi ke dalam deskripsi hasil analisis. Persetujuan etik dikeluarkan oleh Komisi Etik Penelitian Kesehatan
RSU Haji Surabaya dengan nomor: 073/22/KOM. ETIK/2019 pada tanggal 25 April 2019.

\section{Hasil}

Tabel 1. Karakteristik Partisipan

\begin{tabular}{|c|c|c|c|c|c|c|c|}
\hline Kode & $\begin{array}{c}\text { Usia } \\
\text { (Tahun) }\end{array}$ & $\begin{array}{c}\text { Jenis } \\
\text { Kelamin }\end{array}$ & $\begin{array}{c}\text { Lama } \\
\text { HD } \\
\text { (Bulan) }\end{array}$ & $\begin{array}{c}\text { Jadwal HD } \\
\text { (Kali/Minggu) }\end{array}$ & $\begin{array}{c}\text { Status } \\
\text { Keluarga }\end{array}$ & Pekerjaan & $\begin{array}{c}\text { Skala } \\
\text { Tidur } \\
\text { (PSQI) }\end{array}$ \\
\hline P1 & 56 & $\mathrm{P}$ & 120 & 2 & $\begin{array}{l}\text { Menikah, } \\
2 \text { anak }\end{array}$ & Guru & 3 \\
\hline P2 & 44 & $\mathrm{P}$ & 96 & 2 & $\begin{array}{l}\text { Menikah, } \\
1 \text { anak }\end{array}$ & Swasta & 3 \\
\hline P3 & 30 & $\mathrm{P}$ & 48 & 2 & $\begin{array}{l}\text { Menikah, } \\
1 \text { anak }\end{array}$ & $\begin{array}{c}\text { Tidak } \\
\text { Bekerja }\end{array}$ & 3 \\
\hline P4 & 44 & $\mathrm{~L}$ & 60 & 2 & $\begin{array}{l}\text { Menikah, } 1 \\
\text { anak }\end{array}$ & Polri & 4 \\
\hline P5 & 39 & $\mathrm{~L}$ & 11 & 2 & Menikah & Swasta & 5 \\
\hline P6 & 59 & $\mathrm{~L}$ & 72 & 2 & $\begin{array}{c}\text { Menikah, } 5 \\
\text { anak }\end{array}$ & Pensiunan & 3 \\
\hline P7 & 52 & $\mathrm{~L}$ & 120 & 2 & $\begin{array}{l}\text { Menikah, } 2 \\
\text { anak }\end{array}$ & Wiraswasta & 3 \\
\hline P8 & 50 & $\mathrm{~L}$ & 24 & 2 & $\begin{array}{l}\text { Menikah, } 2 \\
\text { anak }\end{array}$ & Wartawan & 5 \\
\hline P9 & 60 & $\mathrm{~L}$ & 18 & 2 & $\begin{array}{l}\text { Menikah, } 3 \\
\text { anak }\end{array}$ & Pensiunan & 5 \\
\hline P10 & 44 & $\mathrm{~L}$ & 9 & 2 & $\begin{array}{c}\text { Menikah, } 1 \\
\text { anak }\end{array}$ & Swasta & 5 \\
\hline P11 & 47 & $\mathrm{~L}$ & 84 & 2 & $\begin{array}{l}\text { Menikah, } 3 \\
\text { anak }\end{array}$ & Wiraswasta & 4 \\
\hline P12 & 41 & $\mathrm{P}$ & 18 & 2 & $\begin{array}{c}\text { Menikah, } 3 \\
\text { anak }\end{array}$ & $\begin{array}{c}\text { Tidak } \\
\text { Bekerja }\end{array}$ & 3 \\
\hline P13 & 52 & $\mathrm{P}$ & 24 & 2 & $\begin{array}{l}\text { Menikah, } 2 \\
\text { anak }\end{array}$ & $\begin{array}{c}\text { Tidak } \\
\text { Bekerja }\end{array}$ & 3 \\
\hline P14 & 56 & $\mathrm{P}$ & 156 & 2 & $\begin{array}{c}\text { Menikah, } 2 \\
\text { anak }\end{array}$ & $\begin{array}{c}\text { Tidak } \\
\text { Bekerja }\end{array}$ & 3 \\
\hline
\end{tabular}


Jumlah partisipan dalam penelitian ini adalah 14 orang dengan rentang usia antara 30-60 tahun. Seluruh partisipan menjalani hemodialisis sebanyak $2 \mathrm{kali} / \mathrm{minggu}$ dengan lama menjalani hemodialisis 9 bulan sampai dengan 156 bulan atau 13 tahun. Partisipan seluruhnya menikah, namun hanya 13 partisipan yang mempunyai anak. Karakteristik partisipan terangkum dalam tabel 1. Terdapat 3 tema utama yang diperoleh dari hasil analisis data wawancara antara lain dukungan keluarga, dukungan lingkungan dan dukungan tenaga kesehatan. Berdasarkan hasil ketiga tema utama tersebut maka dukungan keluarga yang menjadi faktor terbanyak yang membuat kualitas tidur pasien menjadi lebih baik. Tema utama dukungan keluarga dapat diuraikan menjadi tiga sub tema, yaitu kebutuhan akan pendamping, membantu memenuhi kebutuhan, dan perhatian.

\section{Kebutuhan akan pendamping:}

Salah satu kebutuhan akan pendamping adalah keinginan dari partisipan untuk selalu ditemani istri atau anak sehingga merasa aman. Berikut ini pernyataan dari partisipan:

"Saya harus punya semangat gitu dan anak saya itu, saya sampai sekarang kalau saya yang opname, tidur di rumah sakit semua. Itu loh yang membuat saya semangat seperti ini tadi suami saya yang jaga kadang anak saya kalau ada kerepotan gitu loh mas, pokoknya gantian. Ya itu yang penting itu dukungan keluarga itu mas" (P1)

"Ya itu tadi misalnya saya terbangun, saya itu sekarang mas, tidur saya itu, suami kebetulan kan sukanya tidur dibawah di depan di ruang tamu. Ada tempat tidur kecil, saya pindahkan di depan..." (P1)

"Orang sakit itu gak ada yang dipengenin selain ditemenin. Saya di vonis sakit, suami saya resign, dia usaha sendiri, supaya dia punya waktu kan, terutama untuk anak saya, anak saya waktu itu masih kecil banget, jadi seperti itu. Tiap saya drop, hampir selalu ada suami saya dan itu memang menguatkan ya saya selalu mengajak dia ngbrol" (P2)

\section{Membantu memenuhi kebutuhan}

Keluarga selalu hadir setiap saat ketika partisipan membutuhkan bantuan sehingga partisipan tidak khawatir yang dapat berdampak pada tidurnya. Support dana pengobatan dan membantu untuk beraktivitas merupakan salah satu bentuk pemenuhan kebutuhan partisipan oleh keluarga. Berikut ini pernyataan dari partisipan :

"kaki itu sering gatal, itu gak bisa tidur, kadang tidurnya itu istriku tak suruh gosok-gosok itu kalau tidur kayak anak kecil gitu, suruh gosok sampai tidur dibagian punggung biasanya, yang gatal kan punggung, dulu juga kan sedikit-sedikit es batunya habis, saya minta ambilkan istriku" (P5)

"Perhatiannya kalau sudah sakit gini, kalau sudah malam gak bisa tidur ya cepat langsung dipijat ...” (P10)

"Semua biaya juga sudah ditanggung, jadi enggak ada, kalau tanya-tanya gitu, jawabannya (mau diganti tha?). Sekarang semua yang nangung anak saya yang perempuan sama Masnya, saya enggak diberitahu" (P14)

\section{Perhatian}

Perhatian yang diberikan oleh keluarga pada partisipan menjadi salah satu sumber semangat untuk terus menjaga kesehatannya. Salah satu bentuk perhatiannya adalah mengingatkan untuk menjaga makan dan minum serta pengobatan. Berikut ini pernyataan dari partisipan :

"cuma punya anak sama suami ya itu, mereka berdua luar biasa, luar biasalah, ngedukung aku, mendampingi aku, ngejagain aku, luar biasalah, anugerah lah..." (P3)

"Terutama istriku kan selalu support saya, jaga saya, jangan makan ini, jangan makan itu, pasti mengingatkan. Terus apa itu, makanan, gak boleh 
makan ini, masakpun, dia kan tahu sendiri, yang dimasak apa-apa itu, "kamu pingin apa?, gak usah gak boleh, ini saja", ya berartilah, istilahnya 24 jam tiap hari. Sering ngomeli, gak benar sedikit gitu ngomeli, ya gak masalah itu yang membuat semangat dan bertahan sampai sekarang ini" (P5)

"Di kasih tahu adik saya, sampeyan ojo mikir penyakit, sampeyan ndelok anak-anak sampeyan, mesakno sing ijik cilik iki. Insya Alloh sampeyan iso sehat (kamu jangan hanya mikir penyakitnya, kamu harus lihat anakanakmu, kasihan yang masih kecil itu)" (P12)

"Anak saya sangat memperhatikan asupan makan, takaran minum yang harus saya konsumsi, anak kedua saya browsing apa yang boleh dan tidak boleh, anak pertama saya mengawal terus dan aktif bertanya pada perawat" (P13)

\section{PEMBAHASAN}

Setiap individu yang merasakan sakit membutuhkan dukungan dari banyak pihak sejalan dengan sifat manusia sebagai makhluk sosial. Dukungan tersebut dibutuhkan agar pasien tetap semangat dan berjuang melawan rasa sakit yang diderita. Pasien dengan gagal ginjal kronik harus menjalani terapi seumur hidup, penggantian alih fungsi ginjal oleh mesin dirasakan pasien mengubah seluruh ruang gerak mereka. Dukungan dari keluarga saudara, lingkungan kerja dan tempat tinggal sangat membantu pasien memulihkan kondisi fisik psikologis pasca terapi hemodialisis.

Menurut beberapa penelitian, keluarga adalah sumber dukungan yang paling penting dan utama bagi pasien, dan tingkat dukungan sosial tertinggi diterima dari keluarga (Juergensen et al., 2006; Letchmi et al., 2018). Bentuk dukungan keluarga yang dapat diberikan yaitu pendampingan karena keinginan dari partisipan untuk selalu ditemani istri atau anak sehingga merasa aman. Uremia menyebabkan masalah konsentrasi, kehilangan ingatan, dan penilaian yang terganggu, karena itu sebagian besar pasien harus ditemani keluar rumah (Braz et al, 2005). Kondisi pasien yang buruk sebelum dan sesudah dialisis menjadi penyebab pasien hemodialisis perlu ditemani oleh seseorang (Shahgholian \& Yousefi, 2015). Rasa aman akan menghilangkan rasa khawatir sehingga pasien lebih tenang. Ketenangan tersebut yang dibutuhkan oleh pasien hemodialisis sehingga bisa tidur.

Keluarga juga dapat memberikan rasa aman dan nyaman untuk partisipan yang menjalani hemodialisis dengan cara selalu ada untuk menemani tidur malam pasien. Pankhurst \& Home, (1994) menyatakan bahwa secara signifikan wanita lebih banyak merasakan tidur lebih baik dengan pasangannya karena mereka merasa aman. Rasa aman tersebut mempengaruhi durasi tidur dari pasangan yaitu memiliki durasi waktu tidur yang lama secara signifikan dan berangkat tidur lebih awal. Hasil penelitian yang dilakukan oleh Richter et al., (2016) menunjukkan bahwa wanita yang tidur dengan pasangannya memiliki efisiensi tidur yang lebih baik dan menunjukkan latensi tidur yang lebih pendek (Richter et al., 2016). Pasien hemodialiasis memiliki rasa khawatir yang tinggi akan perjalanan penyakitnya dengan kehadiran teman disaat tidur maka akan menimbulkan rasa aman, tenang dan nyaman sehingga pasien bisa mempunyai kualitas tidur yang baik karena rasa khawatir yang menjadi penyebab tidak bisa tidur berkurang.

Keluarga selalu hadir setiap saat ketika partisipan membutuhkan bantuan sehingga partisipan tidak khawatir yang dapat berdampak pada tidurnya. Support dana pengobatan dan membantu untuk beraktivitas merupakan salah satu bentuk pemenuhan kebutuhan partisipan oleh keluarga. Lindner et al., (2015) menyatakan bahwa, beberapa faktor psikososial yang dapat berkontribusi terhadap penurunan kualitas tidur salah satunya adalah kesulitan keuangan. Gejala lanjutan dari pasien hemodialisis adalah menghasilkan kelemahan fisik, kekurangan energi, dan 
kelelahan pada pasien, sampai dengan membutuhkan bantuan untuk melakukan bahkan aktivitas sehari-hari mereka yang paling sederhana (Shahgholian \& Yousefi, 2015). Hadirnya keluarga dalam membantu dalam memenuhi kebutuhan keuangan, memenuhi kebutuhan fisik dan membantu aktivitas sehari-hari pada pasien hemodialisis akan menghilangkan penyebab dari rasa khawatir yang menjadi salah satu pencetus pasien hemodialisis tidak bisa tidur.

Perhatian yang diberikan keluarga sangat berarti untuk pasien hemodialisis karena keluarga juga memberikan motivasi luar biasa agar partisipan terus berjuang dan tidak menyerah akan penyakitnya, serta selalu mengingatkan untuk menjaga makan dan minum yang dapat berakibat mengganggu kualitas tidurnya. Asupan makanan dan minuman pada pasien hemodialisis dapat berdampak pada terganggunya proses tidur pada malam hari. Beberapa partisipan mengeluhkan bahwa setelah memakan makanan yang dilarang dan meminum minuman yang berlebihan, dampaknya akan dirasakan hingga malam hari dan tidur menjadi terganggu. Telah diamati bahwa antara 20 - 78\% pasien tidak patuh terhadap diet dan pembatasan cairan karena kebiasaan dalam kehidupan rutin yang sudah lama berjalan (Beerendrakumar, Ramamoorthy, \& Haridasan, 2018). Keluarga merupakan sebagai salah satu sumber pendukung paling penting oleh pasien hemodialisis. berdasarkan hasil penelitian yang dilakukan oleh (Ahrari, Moshki, \& Bahrami, 2014)Ahrari et al., 2014 diperoleh hasil bahwa dukungan dari keluarga merupakan yang paling berpengaruh dalam kepatuhan pasien hemodialisis untuk mengatur konsumsi cairan dan makanan daripada sumber dukungan sosial lainnya. Pentingnya pengaruh keluarga terhadap kepatuhan pasien hemodialisis dalam mengatur cairan dan diit, maka Sayers et al., (2008) menyarankan bahwa anggota keluarga harus memainkan peran yang lebih besar dalam meningkatkan perilaku perawatan diri. Keluarga sebagai orang yang mempunyai kedekatan hubungan mempunyai keuntungan untuk bisa mengatur dan mengendalikan perilaku pasien hemodialisis terutama dalam pengaturan konsumsi cairan dan makanan.

\section{KESIMPULAN DAN SARAN Kesimpulan}

Dukungan keluarga yang diberikan pada anggota keluarga yang menjalani hemodialisis sehingga dapat memenuhi kebutuhan tidurnya melalui upaya pendampingan, membantu memenuhi kebutuhan dan pemberian perhatian.

\section{Saran}

Dukungan keluarga mempunyai peran yang penting bagi kemampuan pasien hemodialisis untuk mencukupi kebutuhan tidurnya sehingga diperlukan keluarga perlu diberikan pengetahuan terkait peran keluarga di rumah dalam merawat pasien hemodialisis.

\section{DAFTAR PUSTAKA}

Ahrari, S., Moshki, M., \& Bahrami, M. (2014). The Relationship Between Social Support and Adherence of Dietary and Fluids Restrictions among Hemodialysis Patients in Iran, 3(1), 11-19.

https://doi.org/10.5681/jcs.2014.002

Beerendrakumar, N., Ramamoorthy, L., \& Haridasan, S. (2018). Dietary and Fluid Regime Adherence in Chronic Kidney Disease Patients. Tabriz University of Medical Sciences, 7(1), 17-20. https://doi.org/10.15171/jcs.2018.003

Eslami, A. A., Rabiei, L., Khayri, F., Reza, M., \& Nooshabadi, R. (2014). Sleep Quality and Spiritual Well-Being in Hemodialysis Patients, 16(7). https://doi.org/10.5812/ircmj.17155

Febriastuti, H. N. U. R. (2015). KEJADIAN INSOMNIA PADA LANSIA .

Friedman, M., Bowden, V., \& Jones, E. (2010). Buku Ajar Keperawatan 
Keluarga Riset, Teori, Praktik (edisi 5) alih bahasa Achir Yani S. Hamid et al. Jakarta: EGC.

Juergensen, E., Wuerth, D., Finkelstein, S. H., Juergensen, P. H., Bekui, A., \& Finkelstein, F. O. (2006). of Their Satisfaction with Therapy and the Impact of the Therapy on Their Lives, 1191-1196.

https://doi.org/10.2215/CJN.0122040 6

Letchmi, S., Das, S., Halim, H., Zakariah, F. A., Hassan, H., Mat, S., \& Packiavathy, R. (2018). Fatigue experienced by patients receiving maintenance dialysis in hemodialysis units, (2011), 60-64. https://doi.org/10.1111/j.14422018.2011.00579.x

Lindner, A. V., Novak, M., Bohra, M., \& Mucsi, I. (2015). Insomnia in Patients With Chronic Kidney Disease. Seminars in Nephrology, 35(4), 359372.

https://doi.org/10.1016/j.semnephrol. 2015.06.007

Momennasab, M., Ranjbar, M., \& Najafi, S. S. (2018). Comparing the effect of listening to music during hemodialysis and at bedtime on sleep quality of hemodialysis patients: A randomized clinical trial. European Journal of Integrative Medicine, 17(December 2017), 86-91. https://doi.org/10.1016/j.eujim.2017.1 2.001

Pankhurst, F. P., \& Home, J. A. (1994). The Influence of Bed Partners on Movement During Sleep, 17(4), 308315.

Richter, K., Adam, S., Geiss, L., \& Peter, L. (2016). Two in a bed: The influence of couple sleeping and chronotypes on relationship and sleep . An overview, 0528(September).

https://doi.org/10.1080/07420528.201 6.1220388

Sayers, S. L., Ph, D., Riegel, B., Pawlowski, S., Coyne, J. C., Ph, D., \& Samaha, F. F. (2008). Social Support and Self-Care of Patients with Heart Failure, 70-79. https://doi.org/10.1007/s12160-0079003-x

Shahgholian, N., \& Yousefi, H. (2015). Supporting hemodialysis patients: A phenomenological study. Iran J Nurs Midwifery Research, 20(5), 626-633.

Shahgholian, N., \& Yousefi, H. (2018). The lived experiences of patients undergoing hemodialysis with the concept of care : a phenomenological study, 4, 1-7.

Sukriswati, I. (2016). Hubungan Dukungan Keluarga Dengan Kualitas Hidup Pasien Gagal Ginjal Kronik Yang Menjalani Hemodialisa Di RSUD Moewardi Surakarta.

Zubair, U. Bin, \& Butt, B. (2017). Association Of Quality Of Sleep With Cognitive Decline Among The Patients Of Chronic Kidney Disease Undergoing Haemodialysis. Journal of Ayub Medical College, Abbottabad: JAMC, 29(4), 619-622. 